\title{
Transthoracic single-port video-assisted thoracoscopic thymectomy
}

\author{
Kook Nam Han, Hyun Koo Kim, Young Ho Choi \\ Department of Thoracic and Cardiovascular Surgery, Korea University Guro Hospital, Korea University College of Medicine, Seoul, Korea \\ Correspondence to: Hyun Koo Kim. Department of Thoracic and Cardiovascular Surgery, Korea University Guro Hospital, Korea University College \\ of Medicine, 97 Guro-donggil, Guro-gu, Seoul 152-703, Korea. Email: kimhyunkoo@korea.ac.kr.
}

\begin{abstract}
Single-port thoracoscopic surgery has been widely applied in the treatment of thoracic diseases including mediastinal tumors. We present our technique and experience of transthoracic single-port videoassisted thoracoscopic thymectomy. In this case, we performed single-port thoracoscopic thymectomy through a unilateral transthoracic approach. We approached through the fifth intercostal space in the midaxillary line and applied a wound retractor with the multi-hole port device. Conventional and endoscopic devices were used without collision of devices through the port. Transthoracic single-port thoracoscopic thymectomy appears to be a safe and promising technique with port-accessible devices and instruments. A future study of the long-term oncologic outcomes may require more time and more patients to be evaluated to refine the advantages of this procedure.
\end{abstract}

Keywords: Single-port thoracoscopic surgery; mediastinal tumor; thymoma

Received: 25 May 2018; Accepted: 18 July 2018; Published: 08 August 2018.

doi: 10.21037/jovs.2018.07.20

View this article at: http://dx.doi.org/10.21037/jovs.2018.07.20

\section{Introduction}

Thymoma is a rare tumor occurring in the anterior mediastinum. Most patients with thymic tumors are asymptomatic and their tumors are incidentally detected during routine radiologic assessments for other medical conditions (1). For the surgical treatment of thymoma, the conventional surgical approach is total thymectomy including mediastinal fat clearance under median sternotomy (2). Complete clearance of the mediastinal fat tissue with potential ectopic thymic tissue is key for reducing local recurrence of thymoma with myasthenia gravis (3). Alternatively, video-assisted thoracoscopic surgery (VATS) for thymectomy has gained popularity with its safety and feasibility in stages I-II thymoma in recent years $(4,5)$. In the early period of VATS thymectomy, the effects of using a minimal invasive approach for complete thymectomy on the risk of tumor seeding and the oncologic outcome have been debated. However, lower rates of postoperative morbidity and acceptable oncologic efficacy compared to median sternotomy or trans-cervical approach have established VATS thymectomy as one of the standard approaches for thymectomy in selected patients (6-8).

Recently, single-port VATS (SPVATS) has attracted increased attention due to its potential to improve current conventional multi-port VATS with reduced intercostal pain, rapid recovery to normal activity, and better cosmetic outcome $(9,10)$. Since the first report of SPVATS for major lung resection (11), the implementation of this approach has been reported for various thoracic diseases including thymectomy (10,12-14). With the advent of SPVATS, we began using unilateral or bilateral single-port, or hybrid VATS thymectomy for early stages I-II thymoma or thymic tumors in 2010. Our technique for thymectomy was unilateral, bilateral, and hybrid SPVATS depending on tumor location, size, and co-existence of myasthenia gravis. Although another single-port technique such as the subxiphoid (infrasternal) approach could also provide bilateral pleural access and improved surgical view for thymectomy $(15,16)$, we prefer the thoracoscopic approach for better instrumental manipulation and access to the mediastinal fat and more hemodynamic stability. 


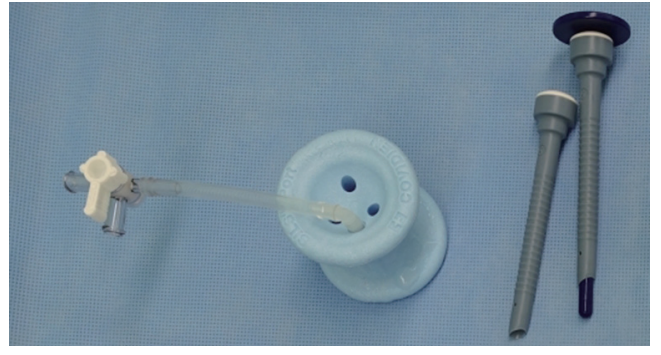

Figure 1 SILS ${ }^{\mathrm{TM}}$ port.

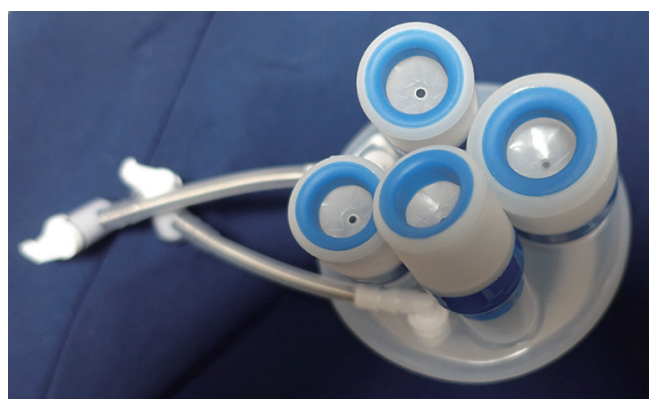

Figure 2 Multi-hole port for single-port surgery (LapSingle Vision $\left.^{\mathrm{TM}}\right)$.

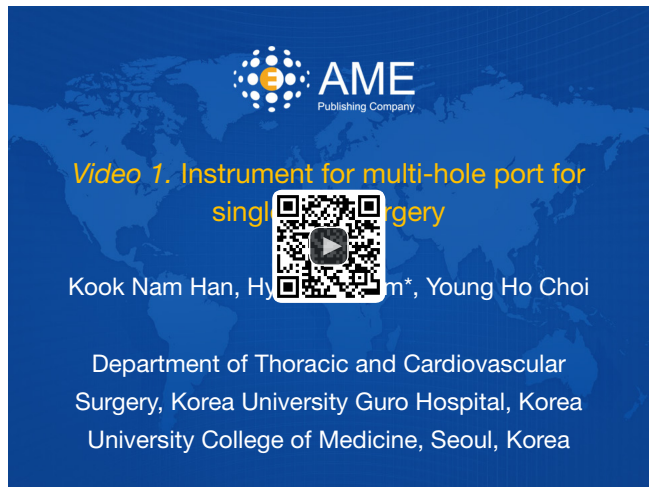

Figure 3 Instrument for multi-hole port for single-port surgery (17). Available online: http://www.asvide.com/article/view/26317

In this paper, we describe our experience of the unilateral single-port thoracoscopic approach for extended thymectomy using a multi-port access device with a wound protector and a multi-port device.

\section{Indication for surgical treatment}

Transthoracic SPVATS for thymectomy could be offered to patients with stages I-II thymoma with or without

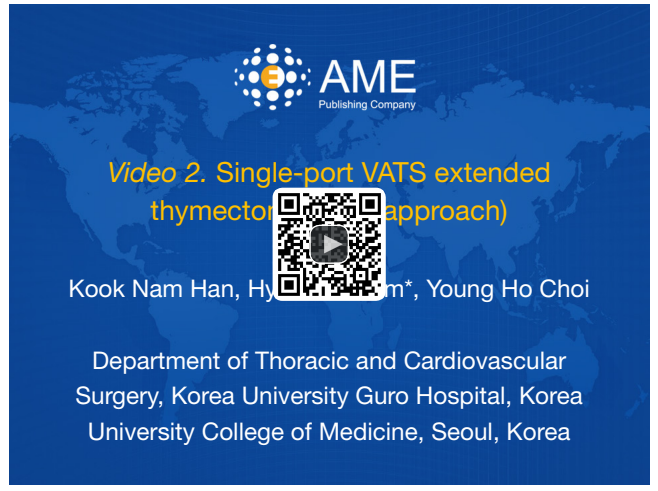

Figure 4 Single-port VATS extended thymectomy (right approach) (18).

Available online: http://www.asvide.com/article/view/26318

myasthenia gravis.

\section{Surgical technique}

In this case video, we performed unilateral (right) SPVATS thymectomy in a patient with thymoma. The patient was positioned in a 30-degree semi supine position with the ipsilateral arm held abducted. One-lung ventilation was supplemented with carbon dioxide $\left(\mathrm{CO}_{2}\right)$ insufflation (to maintain 6-10 $\mathrm{mmHg}$ pressure). An incision of $3 \mathrm{~cm}$ was made at the fifth or sixth intercostal space in the midaxillary line. We used the multi-port devices for singleport surgery such as the single incisional laparoscopic port (SILS $^{\mathrm{TM}}$ port) (Figure 1) or LapSingle Vision ${ }^{\mathrm{TM}}$ (Figure 2) for sealing $\mathrm{CO}_{2}$ gas. The endoscopic instruments we used were a $5 \mathrm{~mm}, 30^{\circ}$ angled thoracoscope, a $5 \mathrm{~mm}$ articulating grasper or dissector (Cambridge Endo ${ }^{\mathrm{TM}}$ ) and a $5 \mathrm{~mm}$ endoscopic energy device. In patients treated with the 4-hole port device (single-port LapSingle Vision ${ }^{\mathrm{TM}}$ ), we used conventional instruments designed for VATS through $10 \mathrm{~mm}$ holes (Figure 3). The anterior mediastinal pleura was dissected from the margin of the phrenic nerve up to the sternal surface, to the level of the internal thoracic veins. Energy devices or vascular clips were used to secure the vessel during the procedure. After dissection of the anterior mediastinal fat, we dissected the upper poles of the thymus and secured feeding vessels from the thymic vessels or innominate veins with vascular clips. The pericardial and diaphragmatic fat was dissected from the right side. Dissection proceeded to the left mediastinal pleura. The resected specimen was placed in an endobag and removed without contamination (Figure 4). One chest drain was 
inserted from the right thorax to the left pleura across the anterior mediastinum.

\section{Results}

The operation was 50 minutes and the patients removed the chest drain at postoperative 2 days and discharged the next day without complication.

\section{Tips and tricks}

Transthoracic single-port thoracoscopic thymectomy appears to be a safe and promising technique with portaccessible devices and instruments.

The choice of using the unilateral, bilateral, or hybrid (multi- and single-port) approach is determined by tumor size, tumor location and the coexistence of myasthenia gravis.

Using single-port devices with multi holes, the surgeon was able to perform transthoracic SPVATS thymectomy with better surgical field and handling control of the instruments.

\section{Conclusions}

Transthoracic single-port VATS approach for thymectomy is a safe and feasible procedure. The anatomy is familiar and easy to access for thoracic surgeons. Hybrid singleport VATS (standard and single-port) thymectomy is an alternative way when a bilateral approach is needed. Further work and development of the techniques and instruments are needed to refine the usage and advantages of this procedure.

\section{Acknowledgments}

Funding: This work was supported by a grant of the Korea Health Technology R\&D Project through the Korea Health Industry Development Institute (KHIDI), funded by the Ministry of Health \& Welfare, Republic of Korea (grant number: HI17C0654).

\section{Footnote}

Provenance and Peer Review: This article was commissioned by the Guest Editor (Jose Luis Danguilan) for the series "Dedicated to the 6th Asian Single-port VATS Symposium 2018" published in Fournal of Visualized Surgery. The article has undergone external peer review.

Conflicts of Interest: All authors have completed the ICMJE uniform disclosure form (available at http://dx.doi. org/10.21037/jovs.2018.07.20). The series "Dedicated to the 6th Asian Single-port VATS Symposium 2018" was commissioned by the editorial office without any funding or sponsorship. The authors have no other conflicts of interest to declare.

Ethical Statement: The authors are accountable for all aspects of the work in ensuring that questions related to the accuracy or integrity of any part of the work are appropriately investigated and resolved. All procedures performed in studies involving human participants were in accordance with the ethical standards of the institutional and/or national research committee(s) and with the Helsinki Declaration (as revised in 2013). Written informed consent was obtained from the patient for publication of this manuscript and any accompanying images.

Open Access Statement: This is an Open Access article distributed in accordance with the Creative Commons Attribution-NonCommercial-NoDerivs 4.0 International License (CC BY-NC-ND 4.0), which permits the noncommercial replication and distribution of the article with the strict proviso that no changes or edits are made and the original work is properly cited (including links to both the formal publication through the relevant DOI and the license). See: https://creativecommons.org/licenses/by-nc-nd/4.0/.

\section{References}

1. Scorsetti M, Leo F, Trama A, et al. Thymoma and thymic carcinomas. Crit Rev Oncol Hematol 2016;99:332-50.

2. Girard N, Mornex F, Van Houtte P, et al. Thymoma: a focus on current therapeutic management. J Thorac Oncol 2009;4:119-26.

3. Davenport E, Malthaner RA. The role of surgery in the management of thymoma: a systematic review. Ann Thorac Surg 2008;86:673-84.

4. Yuan ZY, Cheng GY, Sun KL, et al. Comparative study of video-assisted thoracic surgery versus open thymectomy for thymoma in one single center. J Thorac Dis 2014;6:726-33.

5. Li JF, Hui BG, Li X, et al. Video-assisted thoracic surgery for thymoma: long-term follow-up results and prognostic factors-single-center experience of 150 cases. J Thorac Dis 
2018;10:291-7.

6. Agatsuma H, Yoshida K, Yoshino I, et al. Video-Assisted Thoracic Surgery Thymectomy Versus Sternotomy Thymectomy in Patients With Thymoma. Ann Thorac Surg 2017;104:1047-53.

7. Triviño A, Congregado M, Loscertales J, et al.

Comparative analysis of video-assisted thoracic surgery versus open resection for early-stage thymoma. Cir Esp 2015;93:466-71.

8. Raza A, Woo E. Video-assisted thoracoscopic surgery versus sternotomy in thymectomy for thymoma and myasthenia gravis. Ann Cardiothorac Surg 2016;5:33-7.

9. Caronia FP, Fiorelli A, Arrigo E, et al. Bilateral singleport thoracoscopic extended thymectomy for management of thymoma and myasthenia gravis: case report. J Cardiothorac Surg 2016;11:153.

10. Wu L, Lin L, Liu M, et al. Subxiphoid uniportal thoracoscopic extended thymectomy. J Thorac Dis 2015;7:1658-60.

11. Gonzalez D, Paradela M, Garcia J, et al. Single-port videoassisted thoracoscopic lobectomy. Interact Cardiovasc Thorac Surg 2011;12:514-5.

12. Dmitrii S, Malik A. Uniportal video-assisted thoracic

doi: 10.21037 /jovs.2018.07.20

Cite this article as: Han KN, Kim HK, Choi YH. Transthoracic single-port video-assisted thoracoscopic thymectomy. J Vis Surg 2018;4:164. surgery Ivor Lewis esophagectomy. J Vis Surg 2016;2:163.

13. Shiono H, Nishiki K, Ikeda M. Single-incision surgery with SILS port for anterior mediastinal lesions: initial experience. Surg Laparosc Endosc Percutan Tech 2011;21:e225-7.

14. Chen H, Xu G, Zheng B, et al. Initial experience of singleport video-assisted thoracoscopic surgery sleeve lobectomy and systematic mediastinal lymphadenectomy for nonsmall-cell lung cancer. J Thorac Dis 2016;8:2196-202.

15. Suda T, Sugimura H, Tochii D, et al. Single-port thymectomy through an infrasternal approach. Ann Thorac Surg 2012;93:334-6.

16. Suda T, Hachimaru A, Tochii D, et al. Video-assisted thoracoscopic thymectomy versus subxiphoid single-port thymectomy: initial results $\uparrow$. Eur J Cardiothorac Surg 2016;49 Suppl 1:i54-8.

17. Han KN, Kim HK, Choi YH. Instrument for multi-hole port for single-port surgery. Asvide 2018;5:663. Available online: http://www.asvide.com/article/view/26317

18. Han KN, Kim HK, Choi YH. Single-port VATS extended thymectomy (right approach). Asvide 2018;5:664. Available online: http://www.asvide.com/article/view/26318 